\title{
PENGARUH FAKTOR MUSIMAN PADA PEMODELAN DERET WAKTU UNTUK PERAMALAN DEBIT SUNGAI DENGAN METODE SARIMA
}

\author{
Dadang Ruhiat ${ }^{1}$, Adang Effendi ${ }^{2}$ \\ 1Program Studi Matematika FMIPA Universitas Bale Bandung \\ 2 Program Studi Pendidikan Matematika FKIP Universitas Galuh \\ email: dadangwiraruhiat@gmail.com
}

Dikirim: 6 Februari 2018; Diterima: 6 Maret 2018; Dipublikasikan: 31 Maret 2018

\begin{abstract}
ABSTRAK
Pemodelan dan peramalan deret waktu saat ini berkembang dan banyak digunakan di berbagai bidang termasuk di bidang hidrologi. Salah satu parameter hidrologi yang sangat penting adalah debit sungai. Besaran dan fluktuasi debit sungai pada periode waktu tertentu sangat dipengauhi oleh faktor musiman, yaitu musim hujan dan kemarau. Penelitian ini dilakukan untuk mengetahui pengaruh faktor musiman terhadap kemampuan model dalam menirukan dan meramalkan perilaku dari data debit sungai. Pemodelan dilakukan berbasis kepada pendekatan metode statistik BoxJenkins, yaitu Autoregressive Integrated Moving Average (ARIMA) dengan melibatkan faktor musiman dalam pemodelannya, yang dikenal dengan model Seasonal Autoregressive Integrated Moving Average (SARIMA). Model yang digunakan untuk peramalan adalah model yang terbaik, yaitu model yang memenuhi syarat signifikansi parameter, white noise dan memiliki nilai MAPE (Mean Absolute Percentage Error)yang terkecil. Perbandingan dilakukan terhadap hasil peramalan model-model terbaik, masing-masing terbaik dari model SARIMA dan model ARIMA non musiman, sehingga dapat diketahui pengaruh faktor musiman terhadap hasil pemodelan dan peramalan. Hasil analisis menunjukan ternyatamodel SARIMA terbaik lebih layak digunakan daripada model Arima non musiman.
\end{abstract}

Kata Kunci : SARIMA, Box-Jenkis, Faktor Musiman dan MAPE. 


\section{PENDAHULUAN}

Informasi terkait debit sungai sangat penting dalam rekayasa dan pengelolaan sumber daya air (SDA), karena kelangsungan makhluk hidup dan segala aktivitas manusia di berbagai bidang kehidupan sangat tergantung pada ketersediaan air. Namun ketersediaan airbaik dalam kuantitas maupun kualitas dari waktu ke waktu cenderung menurun seiring dengan munculnya berbagai permasalahan lingkungan.

Terkait dengan potensi ketersediaan air, pendekatan berbasis statistik bisa dilakukan untuk memperkirakan potensi ketersediaan air permukaan,yaitu melalui pemodelan dan peramalan (forecasting) debit sungai. Metode pemodelan dan peramalan deret waktu terus berkembang, dan salah satu metode klasik yang sering digunakan adalah metode Box-Jenkins atau yang dikenal juga dengan Metode Autoregressive Integrated Moving Average (ARIMA).

Beberapa metode dan teknik deret waktu lainnya sudah digunakan untuk pemodelan dan peramalan debit sungai. Lukman dan Susanto (2007), menggunakan teknik Exponential Smoothing, untuk peramalan debit Sungai Cabenge di SWS Walanae-Cenranae. Kemudian Mulyana (2007), menggunakan metode ARMA untuk pemodelan debit air Sungai Cikapundung. Juwono (2010), melakukan kajian mengenai pengaruh perbedaan rerata data debit pada pemodelan deret berkala untuk peramalan debit sungai dengan metode ARFIMA. Suprayogi, Fauzi dan Efrizal (2015), melakukan pengembangan model hidrologi runtun waktu untuk peramalan debit sungai menggunakan Daubechies Wavelet -Adaptive Neuro Fuzzy Inference System pada Sub DAS Siak Bagian Hulu. Namun beberapa metode deret waktu tersebut merupakan metode deret waktu yang tidak melibatkan faktor musiman dalam pemodelannya.

Seiring dengan perkembangan pemodelan deret waktu dan aplikasinya, metode deret waktu musiman mulai banyak digunakan untuk pemodelan dan peramalan di berbagai bidang. Darmawan (2009), melakukan kajian perbandingan model deret waktu pemakaian listrik yang mengandung pola musiman ganda. Sakhabakhsh dan Yarmohammadi (2012), melakukan studi tentang penggunaan Seasonal ARIMA dalam ilmu energi. Bako dan Matias (2013), menggunakan model Arima musiman untuk memprediksi hasil tangkapan ikan.

Penentuan metode yang digunakan untuk pemodelan dan peramalan deret waktu harusdisesuaikan dengan karakteristik data historis. Pemodelan data deret waktu yang teridentifikasi mengandung faktor musiman hendaknyamenggunakan metode-metode yang melibatkan faktor musiman dalam proses pemodelannya. Hal ini dilakukan oleh Ruhiat (2016), dalam tesisnya mencoba menggunakan metode Seasonal ARFIMA untuk pemodelan dan peramalan debit Sungai Cimanuk.

Seperti halnya diketahui bahwa sungai-sungai di wilayah Indonesia pada umumnya sangat dipengaruhi oleh dua faktor musiman, yaitu musim hujan dankemarau. Fluktuasi debit sungai terjadi setiap saat. Debit puncak sungai terjadi di musim hujan dan debit terendah terjadi pada musim kemarau. Kondisi ini terjadi juga pada debit Sungai Citarum yang merupakan sungai terbesar dan terpanjang serta memiliki kawasan Daerah Aliran Sungai (DAS) terbesar di Provinsi Jawa Barat. Sungai Citarum juga merupakan sumber air dari tiga waduk besar multi guna di Jawa barat, yaitu Waduk Saguling, Waduk Cirata dan Waduk Jatiluhur. Atas dasar hal tersebut, studi kasus pada penelitian ini digunakan data historis debit Sungai Citarum hasil pencatatan Pos Duga Air (PDA) Citarum-Nanjung selama 23 tahun terakhirdalam bentuk debit bulanan rata-rata ( $\left.\mathrm{m}^{3} / \mathrm{detik}\right)$. PDA Citarum-Nanjung terletak di Desa Nanjung Kecamatan Batujajar Kabupaten Bandung Barat.

Telaah pada penelitian ini dititikberatkan pada pengaruh faktor musiman yang dimiliki oleh data debit Sungai Citarum terhadap hasil pemodelan dan peramalannya. Berdasarkan atas hal tersebut maka judul dalam penelitian ini adalah "Pengaruh Faktor Musiman Pada Pemodelan Deret 
Waktu Untuk Peramalan Debit Sungai dengan Metoda SARIMA (Studi Kasus Debit Sungai Citarum Pos Duga Debit Nanjung)".

\section{METODE PENELITIAN}

Salah satu metode yang biasa digunakan dalam analisis deret waktu adalah metode BoxJenkin, atau yang dikenal juga dengan metode Autoregressive Integrated Moving Average (ARIMA). Persamaan umum dari model ARIMA (Wei, 2006) adalah sebagai berikut.

$\phi_{p}(B)(1-B)^{d} Z_{t}=\theta_{0}+\theta_{q}(B) a_{t}$

dimana $\phi_{p}(B)=\left(1-\phi_{1} B-\cdots-\phi_{p} B^{p}\right)$ adalah operator $A R$ dan $\theta_{q}(B)=\left(1-\theta_{1} B-\cdots-\theta_{q} B^{q}\right)$ adalah operator MA.

$\theta_{0}$ adalah parameter yang tergantung pada nilai $d$ yang dibedakan menjadi $d=0$ dan $d>0$.

Jika $d=0$, maka proses stasioner dengan

$\Theta_{0}=\left(1-\phi_{1} B-\cdots-\phi_{p} B^{p}\right) \mu$

$\Theta_{0}=\left(1-\phi_{1}-\cdots-\phi_{p}\right) \mu$

dengan demikian $\Theta_{0}$ dihubungkan dengan rata-rata dari proses.

Model seperti pada persamaan (1) dikenal sebagai Model Autoregressive Integrated Moving Average orde $(p, d, q)$ dan ditulis sebagai Model ARIMA(p,d,q). Untuk $p=0$, model ARIMA $(p, d, q)$ juga disebut sebagai model Integrated Moving Average orde $(d, q)$ dan ditulis sebagai model $\operatorname{IMA}(d, q)$. (Wei, 2006).

Data deret waktu seringkali bersifat musiman yang mengalami pengulangan pada setiap periode $S$ tertentu. Untuk data bulanan $S=12$ (12 dalam 1 tahun), untuk obervasi kwartalan $S=4$ (4 dalam 1 tahun). Dengan melibatkan faktor musiman, model ARIMA menjadi model SeasonalARIMA yang memiliki persamaan umum

$\phi_{p}\left(B^{s}\right) \phi_{p}(B)(1-B)^{d}\left(1-B^{s}\right)^{d} Z_{t}(B) \theta_{Q}\left(B^{s}\right) a_{t}$

dengan :

Persamaan diatas ditulis sebagai model SARIMA $(p, d, q)(P, D, Q) s$

$Z_{t}=$ data deret waktu dengan rata-rata $\mu$

$\phi_{p}(B) \quad=$ Persamaan Polinomial $\mathrm{AR}(\mathrm{p})$

$\theta_{q}(B)=$ Persamaan Polinomial MA(q)

$\Phi_{p}\left(B^{S}\right) \quad=$ Persamaan Polinomial Musiman AR(P)

$\Theta_{q}\left(B^{S}\right)=$ Persamaan Polinomial Musiman MA(q)

$(1-B)^{d}=$ Operator pembeda non musiman

$\left(1-B^{S}\right)^{D}=$ Operator pembeda musiman dengan periode $S$

$\varepsilon_{t} \quad=$ Residu deret waktu (diasumsikan white noise)

Model yang digunakan dalam penelitian ini adalah model SARIMA. Pemodelan dan peramalan SARIMA terdiri atas beberapa tahapan, antara lain tahapan identifikasi, estimasi, verifikasi dan peramalan.

\section{Identifikasi Model}

Identifikasi model dilakukan dengan langkah-langkah sebagai berikut :

a. Membuat plot dan melakukan uji stasioneritas

- apabila data deret waktu tidak stasioner dalam rata-rata maka distasionerkan melalui proses differencing, dan

- apabila data deret waktu tidak stasioner d

- alam varian maka distasionerkan melalui transformasi Box-Cox (Wei, 2006).

b. Identifikasi pola musiman, dapat diidentifikasi melalui plot ACF danplot PACF atau melaluiuji statistik melalui metode regresi spectral. 


\section{Penaksiran Parameter Model}

Penaksiran parameter dilakukan untuk setiap alternatif model yang mungkin, kemudian dilanjutkan dengan uji signifikansi parameter model. Model yang parameternya tidak siginifikan dinyatakan tidak layak untuk digunakan, parameter yang tidak signifikan dieliminir sehingga diperoleh model yang setiap parameternya signifikan. Proses penaksiran dan uji signifikansi parameter dapat dilakukan dengan bantuan beberapa software antara lain softwareR, Statisctical Analysis System (SAS) versi 9.1.3. dan Minitab

\section{Diagnostik residual (Diagnostic Checking)}

Uji diagnostik white noise menggunakan uji statistic dari Ljung-Box dengan hipotesis statistik : $\mathrm{H}_{0}: \rho_{\mathrm{i}}=0$ : Residual bersifat white noise; dan $\mathrm{H}_{1}$ : Minimal ada satu $\rho_{\mathrm{i}} \neq 0$ : Residual tidak bersifat white noise Pengujian pada taraf signifikan $a=5 \%$, dengan statistik uji sebagai berikut :

$Q=n^{\prime}\left(n^{\prime}+2\right) \sum_{k=1}^{m} \frac{r_{k}^{2}}{\left(n^{\prime}-k\right)}$

berdistribusi Chi-Kuadrat dengan derajat bebas $(\mathrm{db})=(\mathrm{k}-\mathrm{p}-\mathrm{q}-\mathrm{P}-\mathrm{Q})$, dimana :

$n^{\prime}=\mathrm{n}-(\mathrm{d}+\mathrm{SD})$

$\mathrm{d}=$ ordo pembedaan faktor non musiman

$\mathrm{D}=$ Ordo pembeda faktor musiman

$S=$ Periode musiman

$\mathrm{m}=$ lag waktu maksimum

$r_{k}=$ autokorelasi untuk tim lag $1,2,3, \ldots, \mathrm{k}$

Kriteria uji : Terima Ho jika $Q \leq \chi_{(\alpha ; d b)}^{2}$ dan tolak Ho dalam kondisi lainnya.

\section{Pemilihan Model Terbaik}

Dalam penelitian ini, pemilihan model deret waktu terbaik menggunakan beberapa kriteria, yaitu pemenuhan terhadap syarat signifikansi parameter, white noise dan memiliki kebaikan model yang terbaik. Ukuran kebaikan model yang digunakan adalahMean Absolute Percentage Error yang disingkat dengan MAPE.

\section{HASIL DAN PEMBAHASAN}

\section{Identifikasi Model}

\section{a. Data deret waktu dan uji stasioner}

Gambar 1. memperlihatkan rata-rata relatif tetap sepanjang pergeseran waktu sehingga data deret waktu dikatakan stasioner dalam rata-rata. Namun demikian, pengujian secara statistik tetap dilakukan mengingat pada beberapa bagian grafik ada yang sangat berbeda dari bagian lainnnya. Hasil uji statistik Augmented Dickey-Fuller dengan menggunakan software $R$ memberi hasil nilai $p-$ value $=0,01$, atau lebih kecil dari $\alpha=0,05$ ( $p$-value $=0,01<p=0,05$ ), dengan demikian data stasioner dalam rata-rata.

Terkait dengan kestasioneran dalam varian, Gambar 2., menunjukan kondisi data deret waktu yang tidak stasioner dalam varian dengan nilai $\lambda=0.15$, sehingga data ditransformasikan melalui Box-cox. Gambar 3. menunjukan kondisi data setelah ditransformasikan melalui metode Box-Cox, dengan $\lambda=1.00$ maka sudah stasioner dalam varian. 


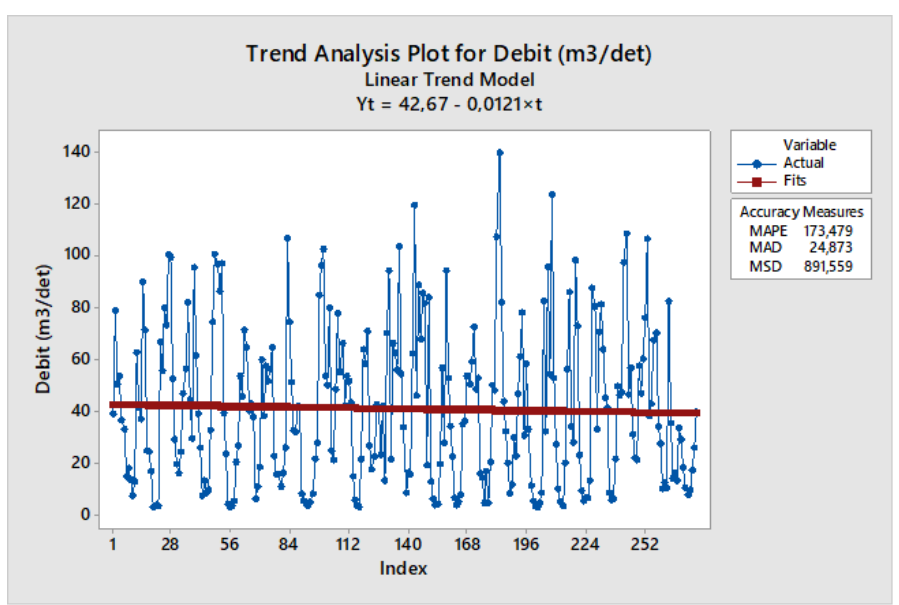

Gambar 1. Plot Data Debit Sungai Cimanuk dalam bulanan Selama 20 Tahun

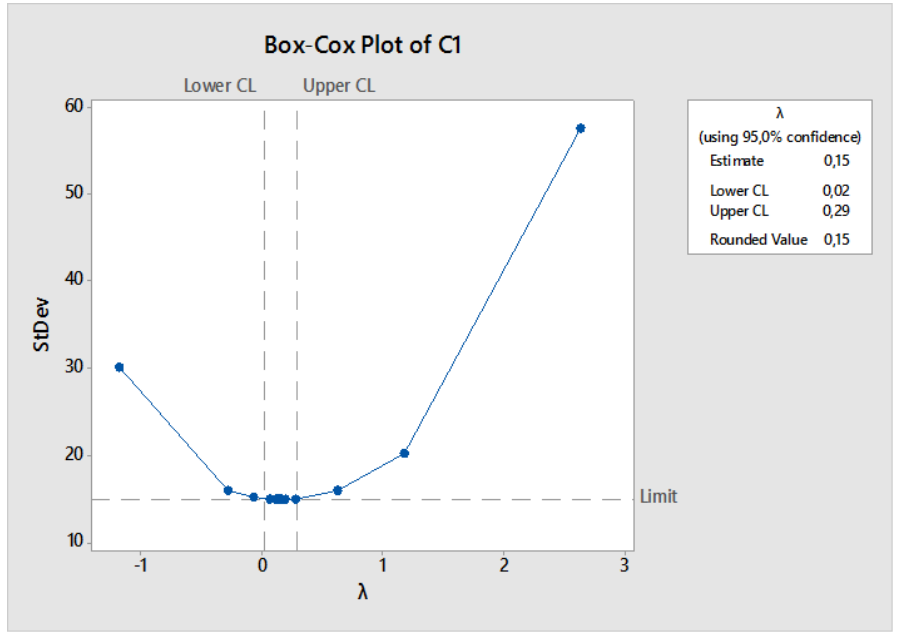

Gambar 2. Box-Cox sebelum transformasi dengan $\lambda=0.15$

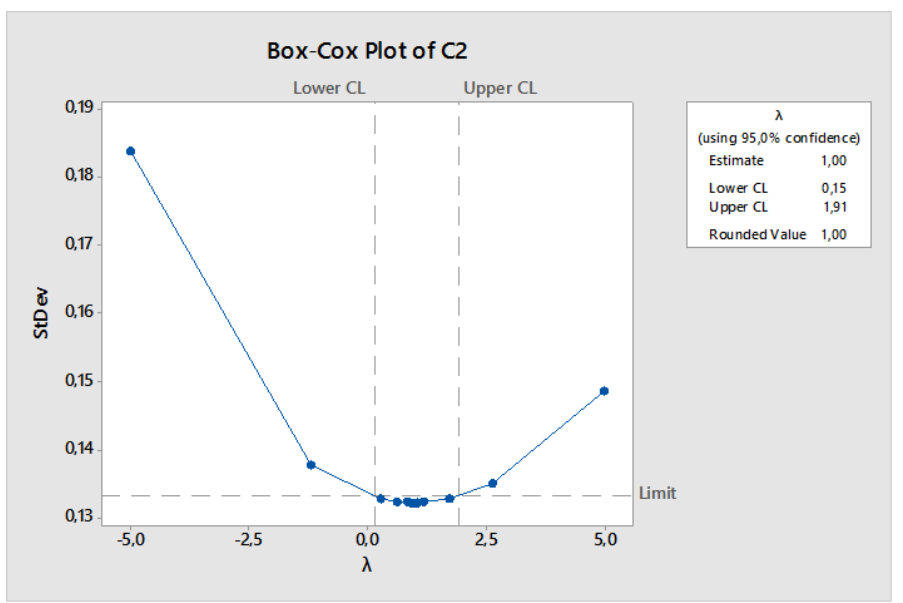

Gambar 3. Box-Cox setelah transformasi dengan $\lambda=1.00$ 


\section{b. Autokorelasi}

Berdasarkan hasil perhitungan statistik uji $\mathrm{T}$ dengan menggunakan bantuan software Minitab diketahui adanya autokorelasi antar $Z_{t}$ dan $Z_{t-k}$. Output menunjukkan pada lag 1 sampai lag 30 diantaranya terdapat: $T>Z_{0.05}(T>1.645)$ atau $-T<-Z_{0.05}(-T<-1.645)$. Secara statistik disimpulkan terjadi autokorelasi antara data deret waktu $Z_{t}$ dan $Z_{t-k}$, dan dengan terpenuhinya asumsi autokorelasi maka analisis data deret waktu dapat dilanjutkan.

\section{c. Pola Musiman}

Plot ACF data debit Sungai Citarum (Gambar 3. (a)) memperlihatkan suatu pola yang berbenuk sinusoidal, hal ini mengindikasikan adanya pola musiman. Pola musiman data deret waktu juga dapat dideteksi secara statistik melalui metode regresi spektral, yaitu metode yang digunakan untuk menelaahperiodesitas dalam kawasan waktu tertentu. Berdasarkan hasil perhitungan uji regresi

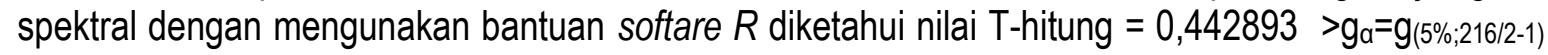
$=g_{(5 \% ; 107)}=0.13135$, dengan demikian data deret waktu debit Sungai Citarum PDA Nanjung dipengaruhi oleh faktor musiman dengan periodesitas 12 .

\section{Penaksiran Parameter Model dan Penentuan Model Terbaik}

\section{a. Model SARIMA}

Identifikasi model SARIMA yang cocok untuk digunakan, dilakukan melalui Plot ACF (Autocorrelation Function) dan PACF (Partial Autocorrelation Function) data deret waktu seperti yang disajikan pada Gambar 4 dan Gambar 5.

Grafik pada Gambar 4. menunjukan bahwa plot ACF berpola dies down sinusoidal, sedangkan grafik pada Gambar 5. menunjukan plot PACF berpola dies down eksponensial. Berdasarkan pola grafik plot ACF dan plot PACF tersebut maka model yang diduga cocok untuk digunakan dalam pemodelan adalah model kombinasi antara model Autoregressive dan Moving Average (mixed autoregressive and moving average model ) yang dipengaruhi faktor musiman dengan periodesitas 12 . Dengan demikian diduga model yang cocok digunakan adalah model $\operatorname{SARIMA}(p, d, q)(P, D, Q)^{S}$

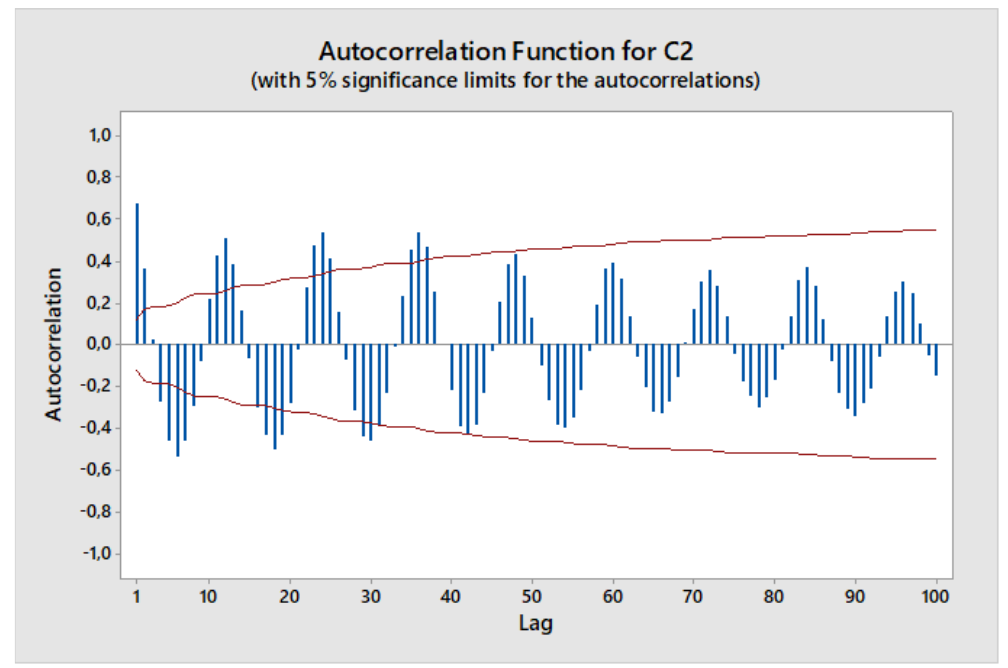

Gambar 4Grafik ACF data debit sungai Citarum PDA Nanjung

Cara sitasi: Ruhiat, D., dan Effendi, A. 2018. Pengaruh Faktor Musiman pada Pemodelan Deret Waktu untuk Peramalan Debit Sungai dengan Metode Sarima. Teorema: Teori dan Riset Matematika Vol 2, No 2 (2018). Hal 117-128 


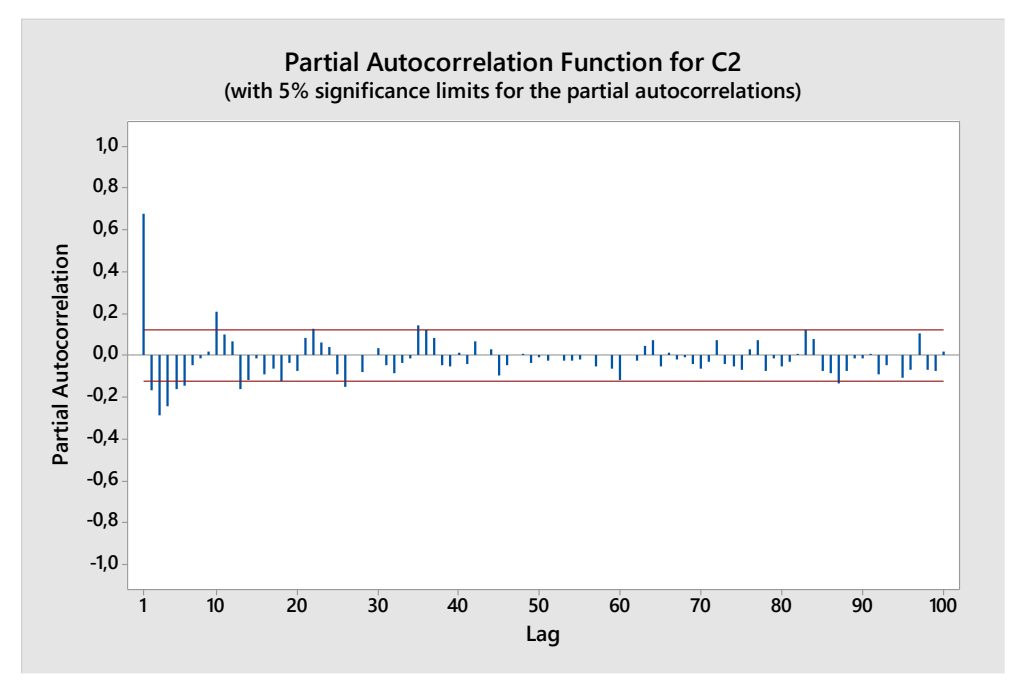

\section{Gambar 5.Grafik PACF Debit Sungai Citarum PDA Nanjung}

\section{b. Penaksiran dan uji Signifikansi Parameter}

Penaksiran dan pengujian parameter menggunakan software minitab. Secara keseluruhan diperoleh 41 model SARIMA yang memenuhi syarat signifikansi parameter. Berikut ini salah satu contoh output dari proses penaksiran dan uji signifikansi parameter untuk model $\operatorname{SARIMA}(3,0,1)(2,0,0)^{12}$.

\begin{tabular}{|c|c|c|c|c|}
\hline \multirow[b]{2}{*}{ Type } & \multicolumn{4}{|c|}{ Final Estimates of Parameters } \\
\hline & Coef & SE Coef & $\mathrm{T}$ & $\mathrm{P}$ \\
\hline AR1 & 1,4569 & 0,0647 & 22,53 & 0,000 \\
\hline AR2 & $-0,3746$ & 0,1117 & $-3,35$ & 0,001 \\
\hline AR3 & $-0,1360$ & 0,0644 & $-2,11$ & 0,036 \\
\hline SAR12 & 0,3110 & 0,0625 & 4,97 & 0,000 \\
\hline SAR2 4 & 0,2840 & 0,0650 & 4,37 & 0,000 \\
\hline MA1 & 0,9846 & 0,0000 & 37011,32 & 0,000 \\
\hline Cons & 5,03668 & 0,000199 & 184,36 & 0,000 \\
\hline & Mean & 68637 &, 00915 & \\
\hline
\end{tabular}

\section{c. Diagnostic Checking}

Pengujian untuk mengetahui apakah residual white noise dilakukan melalui metode LjungBox yang dalam proses penghitungannya menggunakan bantuan software minitab. Beberapa model $\operatorname{SARIMA}(p, 0, q)(P, 0, Q)^{12}$ yang memenuhi syarat signifikansi parameter dan dinyatakan memiliki residual yang white noise disajikan pada Tabel 1 .

\section{d. Pemilihan Model Terbaik}

Model terbaik adalah model yang memenuhi syarat signifikansi parameter, memiliki residual yang white noisedan memiliki nilai ukuran kebaikan model terkecil, yang dalam penelitian ini digunakan Mean Absolute Percentage Error (MAPE) in sample dan MAPE out of sample. Perhitungan nilai MAPE dilakukan berdasarkan panjang peramalan yang diinginkan. Daftar nilai MAPE in sample untuk masing-masing model disajikan pada Tabel 1.

Pada Tabel 1 tampak bahwa model SARIMA $(2,0,2)(1,0,0)^{12}$ merupakan model terbaik, karena selain memiliki parameter yang signifikan dan whitenoise juga memiliki nilai MAPE terkecil, yaitu sebesar $36,9 \%$ untuk peramalan 12 bulan kedepan. Dua model terbaik lainnya adalah model model SARIMA $(4,0,3)(0,0,1)^{12}$ sdan model SARIMA $(3,0,1)(2,0,0)^{12}$ yang masing-masing mempunyai nilai MAPE untuk peramalan 12 bulan kedepan $38,4 \%$ dan $38,8 \%$. 


\section{Peramalan}

Berdasarkan grafik pada Gambar 4 (a) dan Gambar 4 (b), secara visual nampak bahwa data hasil peramalan (forecasting) debit sungai selama 24 (dua puluh empat) bulan ke depan (out of sample) untuk model terbaik pertama yaitu $\operatorname{SARIMA}(2,0,2)(1,0,0)^{12}$ nampak kurang mampu menirukan perilaku dari historis debit sungai dibandingkan dengan model terbaik ketiga (SARIMA $(3,0,1)(2,0,0)^{12}$.

Tabel 2. Nilai MAPE In Sample Model SARIMA(p,d,q)(P,D,Q)

\begin{tabular}{ccc}
\hline \multirow{2}{*}{ Model SARIMA(p, d, q)(P,D,Q)S } & \multicolumn{2}{c}{ MAPE } \\
\cline { 2 - 3 } & 12 Bulan & 24 Bulan \\
\hline SARIMA $(2,0,2)(1,0,0) 12$ & 36.94 & 50.42 \\
SARIMA $(4,0,3)(0,0,1) 12$ & 38.44 & 56.36 \\
SARIMA $(3,0,1)(2,0,0) 12$ & 38.81 & 53.81 \\
SARIMA $(0,0,2)(1,0,1) 12$ & 40.10 & 50.92 \\
SARIMA $(3,0,2)(1,0,1) 12$ & 40.94 & 48.91 \\
SARIMA $(2,0,2)(0,0,1) 12$ & 42.02 & 57.75 \\
SARIMA $(1,0,0)(2,0,0) 12$ & 44.20 & 59.12 \\
SARIMA $(1,0,0)(2,0,0) 12$ & 44.20 & 59.12 \\
SARIMA $(0,0,3)(4,0,0) 12$ & 50.29 & 62.28 \\
SARIMA $(0,0,3)(2,0,0) 12$ & 50.77 & 57.70 \\
SARIMA $(2,0,2)(2,0,0) 12$ & 50.80 & 59.32 \\
SARIMA $(0,0,3)(5,0,0) 12$ & 50.81 & 57.96 \\
$\operatorname{SARIMA}(2,0,2)(3,0,0) 12$ & 53.44 & 61.57 \\
SARIMA $(0,0,3)(3,0,0) 12$ & 53.61 & 64.45 \\
\hline
\end{tabular}

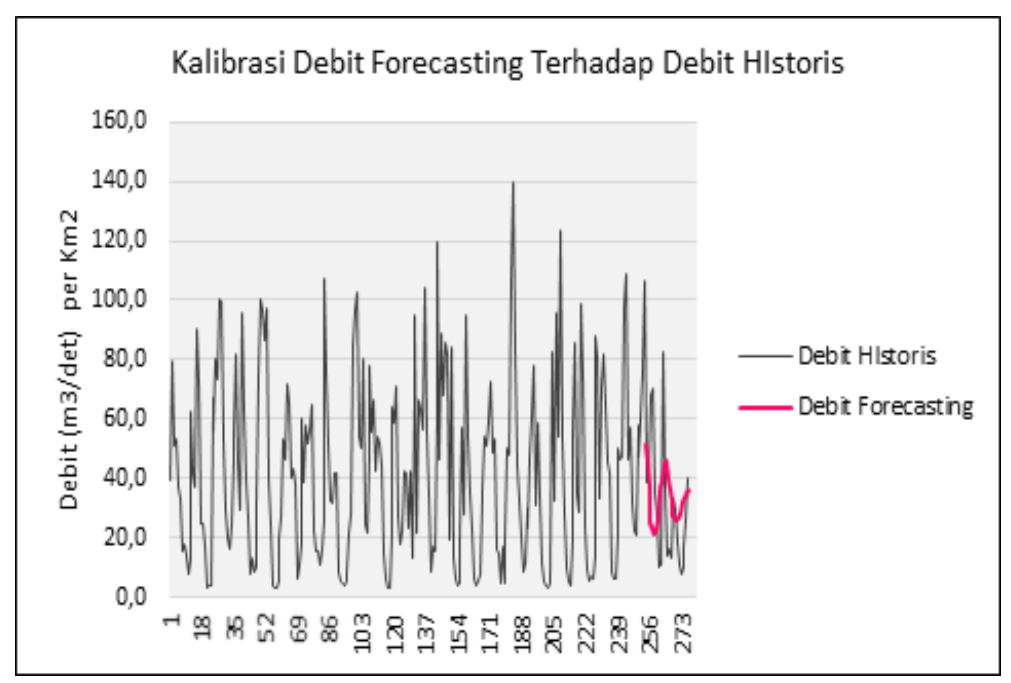

\section{Gambar 6. Grafik model SARIMA $(2,0,2)(1,0,0)^{12}$}

Kondisi seperti ini perlu dilakukan verifikasi model melalui kalibrasi hasil peramalan masing-masing model dengan data aktualnya, dalam hal ukuran kebaikan modelnya yang digunakan MAPE out of sample. Model dengannilai MAPE in sample kecil idealnya memiliki nilai MAPE out of sample yang relatif kecil pula, namun dalam kenyataannya hal ini bisa saja terjadi sebaliknya. 


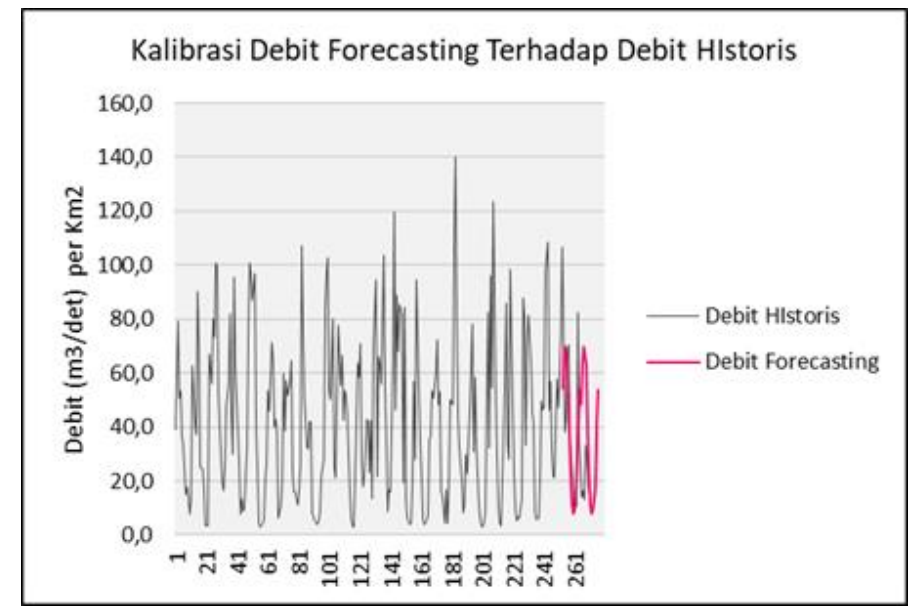

Gambar 7. Grafik Model SARIMA(3,0,2)(1,0,1) 12

\section{Kalibrasi Model}

Verifikasi model terbaik dalam penelitian ini digunakan ukuran kebaikan model, yaitu MAPEout of sampleantara data hasil peramalan model dengan data aktualnya.Niilai MAPE out of sample untuk masing-masing model yang disajikan pada Tabel 3.

Tabel 3. menunjukan model terbaik pertama dan kedua yang berdasarkan nilai MAPE in sample ternyata memiliki nilai MAPE out of sample yang relatif besar bahkan berada pada urutan 12 dan 13. Hal ini bisa dikatakan kedua model tersebut tidak konsisten dalam peramalan. Lain halnya dengan model terbaik ketiga, keempat dan kelima, model-model tersebut memiliki nilai MAPE out sample yang relatif lebih terkecil diantara model-model lainnya. Dengan demikian tiga model terbaik berdasarkan hasil verifikasi model untuk peramalan debit Sungai Citarum PDA Nanjung adalah Model $\operatorname{SARIMA}(3,0,1)(2,0,0)^{12}$, model SARIMA $(3,0,2)(1,0,1)^{12}$ dan SARIMA $(0,0,2)(1,0,1)^{12}$.

Tabel 3. Nilai MAPE Out of Sample

\begin{tabular}{ccc}
\hline \multirow{2}{*}{ Model SARIMA(p,d, q)(P,D,Q)S } & \multicolumn{2}{c}{ MAPE } \\
\cline { 2 - 3 } & 12 Bulan & 24 Bulan \\
\hline SARIMA $(3,0,1)(2,0,0)^{12}$ & 45.24 & 71.65 \\
$\operatorname{SARIMA}(3,0,2)(1,0,1)^{12}$ & 45.83 & 73.62 \\
$\operatorname{SARIMA}(0,0,2)(1,0,1)^{12}$ & 45.9 & 73.51 \\
$\operatorname{SARIMA}(0,0,3)(4,0,0)^{12}$ & 46.34 & 82.38 \\
$\operatorname{SARIMA}(0,0,3)(5,0,0)^{12}$ & 47.38 & 78.24 \\
$\operatorname{SARIMA}(1,0,0)(2,0,0)^{12}$ & 48.4 & 73.28 \\
$\operatorname{SARIMA}(2,0,2)(3,0,0)^{12}$ & 49.34 & 85.24 \\
$\operatorname{SARIMA}(0,0,3)(3,0,0)^{12}$ & 51.18 & 89.1 \\
$\operatorname{SARIMA}(1,0,0)(2,0,0)^{12}$ & 60.99 & 102.99 \\
$\operatorname{SARIMA}(0,0,3)(2,0,0)^{12}$ & 62.32 & 105.64 \\
$\operatorname{SARIMA}(2,0,2)(2,0,0)^{12}$ & 66.73 & 117.11 \\
$\operatorname{SARIMA}(4,0,3)(0,0,1)^{12}$ & 72.51 & 85.81 \\
$\operatorname{SARIMA}(2,0,2)(1,0,0)^{12}$ & 80.67 & 93.51 \\
$\operatorname{SARIMA}(2,0,2)(0,0,1)^{12}$ & 81.87 & 92.8 \\
\hline
\end{tabular}

Dikirim: 6 Februari 2018; Diterima: 6 Maret 2018; Dipublikasikan: 31 Maret 2018

Cara sitasi: Ruhiat, D., dan Effendi, A. 2018. Pengaruh Faktor Musiman pada Pemodelan Deret Waktu untuk Peramalan Debit Sungai dengan Metode Sarima. Teorema: Teori dan Riset Matematika Vol 2, № 2 (2018). Hal 117-128 


\section{Hasil Pemodelan dan Peramalan melalui metode ARIMA}

Proses pemodelan deret waktu debit sungai Citraum melalui metode ARIMA cukup sulit untuk mendapatkan model terbaik yang memenuhi asumsi white noise dalam residual. Diperoleh 14 model ARIMA $(p, 0, q)$ atau ARIMA $(p, q)$ yang memenuhi syarat siginikansi parameter namun tidak white noise. Peramalan dengan menggunakan model-model $\operatorname{ARIMA}(p, 0, q)$ diketahui memiliki MAPE out of sample jauh lebih besar dari metode SARIMA yaitu di atas $60 \%$ (>60\%).

\section{KESIMPULAN}

1. Beberapa kesimpulan yang diperoleh dari hasil penelitian ini adalah sebagai berikut :Pemodelan deret waktu untuk debit Sungai Citarum Pos Duga Air Nanjung yang melibatkan faktor musiman dalam proses pemodelannya menghasilkan beberapa alternatif model terbaik, yakni model Seasonal ARIMA dengan nilai $d=0$ dan $D=0$ serta memiliki nilai periodesitas $(S)=12$. Secara umum model tersebut ditulis dengan $\operatorname{SARIMA}(p, 0, q)(P, 0, Q)^{12}$.

2. Model deret waktu terbaik selain memenuhi syarat signifikansi parameter dan residual yang white noisejuga harus memiliki nilai MAPE yang relatif kecil dibandingkan model lainnya. Model terbaik.

3. Peramalan data deret waktu dilakukan menggunakan model terbaik yang diperoleh melalui metode Seasonal ARIMA. Oleh karena itu, peramalan data debit Sungai Citarum berdasarkan data debit historis Sungai Citarum PDA Nanjung dilakukan menggunakan model Model SARIMA $(3,0,1)(2,0,0) 12$;modelSARIMA(3,0,2)(1,0,1)12; dan model SARIMA $(0,0,2)(1,0,1) 12$.

\section{REKOMENDASI}

Pemodelan dan peramalan deret waktu untuk debit Sungai Citarum PDA Nanjung dengan metode Seasonal ARIMA belum memberikan hasil yang memuaskan, hal ini karena nilai MAPE hasil peramalan model terbaik yang masih relatif besar, yaitu 36,94 \% untuk MAPE in sampledan 45,24 $\%$ untuk MAPE out of sample. Untuk itu perlu dilakukan penelitian lanjutan untuk mencari model yang lebih baik dengan menggunakan pendekatan metode lain yang lebih cocok atau sesuai dengan karakteristik data deret waktu historis pembangun model.Beberapa metode yang direkomendasikan untuk digunakan dalam pemodelan dan peramalan deret waktu yang mengandung pola musiman antara lain metode Spectrum Singular Analysis (SSA), SARFIMA, metode Regresi Spektral atau metode lainnya.

\section{UCAPAN TERIMAKASIH}

Paper ini merupakan salah satu luaran dari penelitian pada skema Penelitian Dosen Pemula. Untuk itu penulis mengucapkan terima kasih yang sebesar-besarnya kepada Direktorat Riset dan Pengabdian kepada Masyarakat (DRPM), Kementerian Riset, Teknologi dan Perguruan Tinggi (Kemenristekdikti) yang telah mendanai penelitian ini. 


\section{DAFTAR PUSTAKA}

Bako, H. Y., Matias, Monica. H., (2013).Predictive Modeling of Pelagic Fish Catch in Malaysia Using Seasonal Arima Models", Science Group Publishing, 2013:2(3): 136-140 Technology and Human Development, Universiti Tun Hussein Onn Malaysia.

Darmawan, G. (2009). Perbandingan Model pada Data Deret Waktu Pemakaian Listrik Jangka Pendek yang Mengandung Pola Musiman Ganda. Makalah Seminar Nasional Matematika dan Pendidikan Matematika FMIPA Universitas Negeri Yogyakarta, Yogyakarta.

Juwono, P.T. (2010). Pengaruh Perbedaan Rerata Data Debit Pada Pemodelan deret Berkala untuk Peramalan Debit Sungai dengan Metode ARFIMA. Jurnal Pengairan, Vol 1. No.2, 2010. Fakultas Teknik UNIBRAW

Lukman,M., Susanto,E. (2007). Pemodelan Deret Waktu Menggunakan Teknik Exponential Smoothing untuk Peramalan Debit Sungai (Studi kasus Sungai Cabenge SWS WalanaeCenranae. Artikel PIT Himpunan Ahli Teknik Hidraulik Indonesia, Fakultas Teknik, Universitas Diponogoro, Semarang.

Mulyana. (2007). Pemodelan Debit Air Sungai (Studi kasus DAS Cikapundung). Jurusan Statistika, Universitas Padjadjaran, Bandung.

Ruhiat, D. (2016). Penerapan Model Seasonal Autoregressive Fractionally Integrated Moving Average (Sarfima) Untuk Peramalan Debit Air Sungai Cimanuk. Tesis Statistika Terapan. Universitas Padjadjaran.

Sakhabakhsh,L., Yarmohammadi. (2012).An Empirical Study of the Usefulness of SARFIMA in Energi Science. Internastional Journal of Energy Science, Vol. 2., No.2. 2012, PP 59-63.

Suprayogi,I., Fauzi, Manyuk; Efrizal, Eki. (2015).Pengembangan Model Hidrologi Runtun Waktu untuk Peramalan Debit Sungai Menggunakan Daubechies Wavelet -Adaptive Neuro Fuzzy Inference System (Study Kasus Sub DAS Siak Bagian Hulu). Annual Civil Engineering Seminar 2015, Pekanbaru ISBN :978-979-792-636-6, Fakultas Teknik, Universitas Riau, Pekanbaru

Wei, W. W.S. (2006).Time Series Analysis, Department of Statistics, Temple University, Philadelphia, Pennsylvania, USA. 
-128 Jurnal Teori dan Riset Matematika (TEOREMA) Vol. 2 No. 2, Hal, 128-128, Maret 2018 